\title{
Morphological study of the tuberculum sphenoidalis in macerated skulls of adult individuals
}

\author{
N. Alves ${ }^{1}$, N.F. Deana ${ }^{2}$ \\ ${ }^{1}$ CIMA Research Group, Faculty of Dentistry, Universidad de La Frontera, Temuco, Chile \\ 2Private Physical Therapist, Temuco, Chile
}

[Received 25 November 2014; Accepted 28 February 2015]

\begin{abstract}
The tuberculum sphenoidalis (TS) is an anatomical structure of variable form located at the anterior extremity of the infratemporal crest of the greater wing of the sphenoid. The object of this study was to analyse the morphology and frequency of the TS in macerated skulls. We examined 304 macerated skulls belonging to individuals of both sexes, Amerindian and Caucasian. The TS were classified morphologically into spiniform, pyramidal and laminar. TS was present in $96.3 \%$ of the skulls; the spiniform type was most frequent (40.3\%), followed by pyramidal (37\%) and laminar (19\%). The most frequent type in females and Amerindian individuals was spiniform; in males and Caucasian individuals, the most frequent types were spiniform and pyramidal. The TS is a frequent anatomical structure on the sphenoid bone. The spiniform and pyramidal types are both very frequent. We suggest that it should be incorporated into international anatomical terminology. The term 'sphenoidal tuberculum' may be the most appropriate. (Folia Morphol 2015; 74, 4: 465-469)
\end{abstract}

Key words: tuberculum sphenoidalis, sphenoid bone, international anatomical terminology

\section{INTRODUCTION}

The tuberculum sphenoidalis (TS) is an anatomical structure located at the anterior extremity of the infratemporal crest of the greater wing of the sphenoid bone, which is the point of origin of the deep fascicle of the temporal muscle $[1,24]$. It is variable in form, being described as a process in the form of a spine $[8,27]$, a tuberculum $[7,23]$ or a large tuberculum $[23]$.

Classic anatomy textbooks use various terms to designate this structure. The term 'sphenoidal tubercle' is the most used in the literature $[2,4,6,16$, $18,19-22,24,26,29,30]$; however this structure has also been described as: tuberculum spinosum $[3,5,12-14,25,28]$; infratemporal spine [10, 11]; pterygoid spine [17] and sphenoidal spine [15].
Although amply mentioned by classic authors, this structure has not yet been incorporated into international anatomical terminology.

The object of this study was to analyse the morphology and frequency of the TS, considering sex and race.

\section{MATERIALS AND METHODS}

We examined 304 macerated skulls, both sexes, Amerindian and Caucasian individuals, aged 18-100 years. Skulls for which the sex and/or skin colour were not identified were excluded from the study. The study included 41 Caucasian females (average age 42.64 years), 61 Amerindian females (average age 37.53 years), 119 Caucasian males (average age 47.25 years) and 83 Amerindian males (average age 39.04 years). 
Each skull was analysed on both sides, observing the presence or absence of the TS. When present, the TS was classified into one of 3 morphological types, based on Ramalho et al. [24]:

- pyramidal - when the TS presented three faces and three margins with or without an apex, like a triangular pyramid (Fig. 1A);

- spiniform - when the TS took the form of pointed, conoid, osseous salients, in varying degrees of development (Fig. 1B);

- laminar - when the TS took the form of laminar osseous salients (Fig. 1C).

The TS was considered absent when there was no osseous prominence perceptible to the touch or to a variation in the incidence of light.

We also analysed the frequency, symmetry and racial and sexual differences of each type of TS.

The data obtained were tabulated and analysed using $\chi^{2}$ test and Fisher's exact test, as applicable. A $p$ value $<0.05$ was considered statistically significant.

\section{RESULTS}

\section{Analysis of the frequency of TS types}

Tuberculum sphenoidalis were present in $96.3 \%$ of the skulls; the spiniform type was most frequent $(40.3 \%)$, followed by pyramidal (37\%) and laminar (19\%). Skulls with absent TS totalled only 3.7\%.

The spiniform type was most frequent in Amerindian females, the pyramidal type was most frequent in Amerindian males, and the laminar type was most frequent in Caucasian males and Amerindian females. In Caucasian females, Caucasian males and Amerindian males, the spiniform and pyramidal types presented similar percentages, both being very frequent. The absence of TS showed a low frequency in all studied groups. Caucasian females presented the highest percentage of absence ( $8.5 \%)$, followed by Amerindian females (5.7\%), Caucasian males (2.9\%) and Amerindian males (1.3\%) (Table 1).

\section{Analysis by race}

We observed that Caucasian individuals presented equal percentages of spiniform and pyramidal TS, while Amerindian individuals presented a higher percentage of spiniform TS. The laminar type of TS occurred more frequently in Caucasian individuals than in Amerindian (Table 2). We also observed that the laminar TS was more prevalent in Caucasian males than in Amerindian males $(p<0.0001)$ (Table 1).

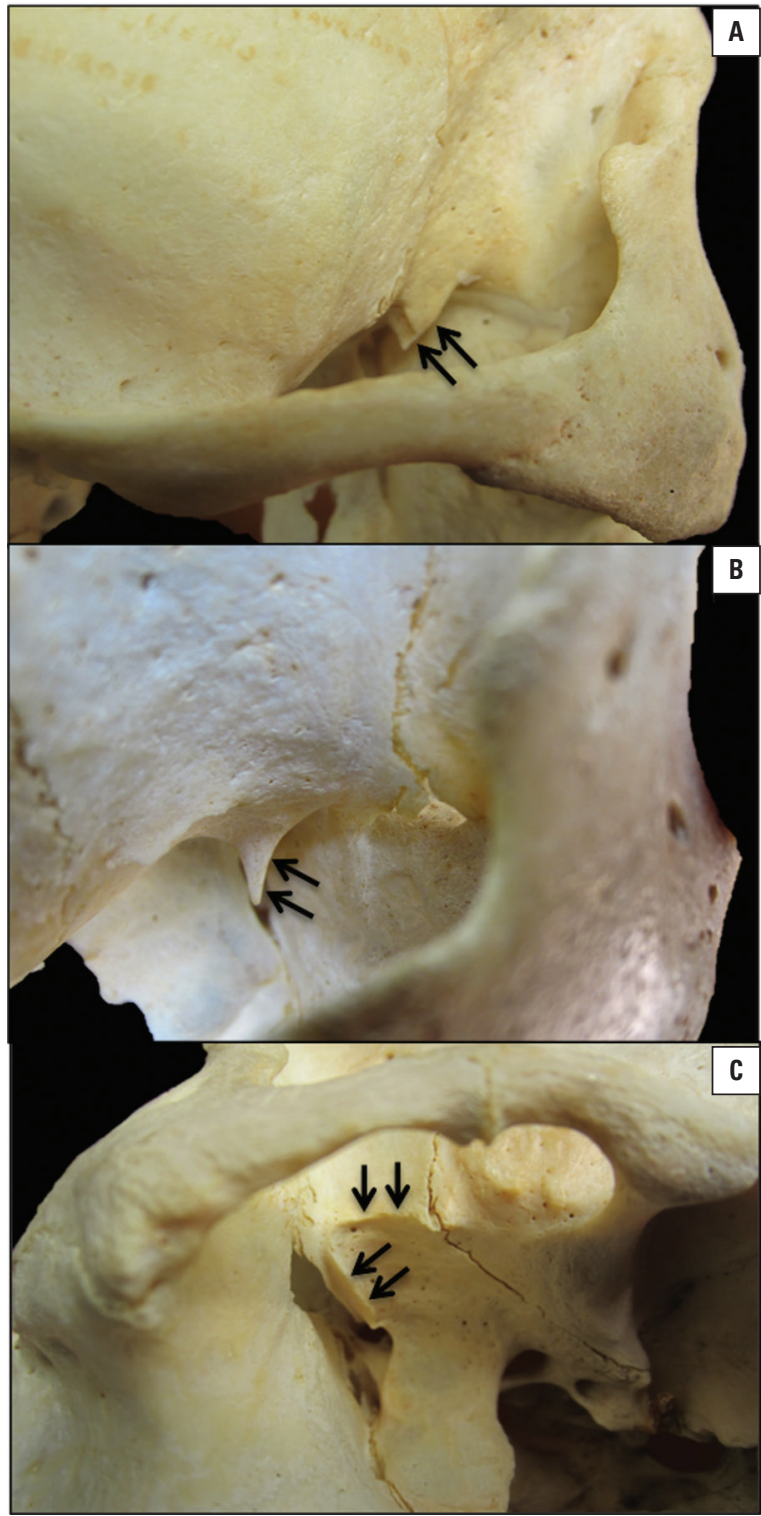

Figure 1. A. Posterolateral view of the skull showing a pyramidal tuberculum sphenoidalis (TS ) (arrows); B. Posterolateral view of the skull showing a spiniform TS (arrows); C. Inferolateral view of the skull showing a laminar TS (arrows).

There was a significant statistical difference between races only in spiniform TS $(p=0.04)$. We observed that there were more absences in females than in males. The absence of TS was infrequent in Caucasian and Amerindian individuals (Table 2).

\section{Analysis by sex}

In females the spiniform type was more frequent than the pyramidal and laminar types. In males both the pyramidal and spiniform types were very frequent. The laminar type presented similar percentages in both males and females, and was the least frequent overall. We observed that females 
Table 1. Percentage of different types of tuberculum sphenoidalis and its absence in Caucasian males, Amerindian males, Caucasian females and Amerindian females

\begin{tabular}{|c|c|c|c|c|c|c|c|c|c|c|c|c|}
\hline & \multicolumn{3}{|c|}{ Spiniform } & \multicolumn{3}{|c|}{ Pyramidal } & \multicolumn{3}{|c|}{ Laminar } & \multicolumn{3}{|c|}{ Absent } \\
\hline & $\begin{array}{l}\text { Right } \\
\text { side }\end{array}$ & $\begin{array}{l}\text { Left } \\
\text { side }\end{array}$ & $\begin{array}{l}\text { Both } \\
\text { sides }\end{array}$ & $\begin{array}{l}\text { Right } \\
\text { side }\end{array}$ & $\begin{array}{l}\text { Left } \\
\text { side }\end{array}$ & $\begin{array}{l}\text { Both } \\
\text { sides }\end{array}$ & $\begin{array}{l}\text { Right } \\
\text { side }\end{array}$ & $\begin{array}{l}\text { Left } \\
\text { side }\end{array}$ & $\begin{array}{l}\text { Both } \\
\text { sides }\end{array}$ & $\begin{array}{l}\text { Right } \\
\text { side }\end{array}$ & $\begin{array}{l}\text { Left } \\
\text { side }\end{array}$ & $\begin{array}{l}\text { Both } \\
\text { sides }\end{array}$ \\
\hline Caucasian males & $33.6 \%$ & $39.5 \%$ & $36.5 \%$ & $41.2 \% *$ & $32.7 \% *$ & $37 \%$ & $22.7 \%$ & $24.4 \%$ & $23.6 \% * *$ & $2.5 \%$ & $3.4 \%$ & $2.9 \%$ \\
\hline Amerindian males & $39.7 \%$ & $45.8 \%$ & $45.2 \%$ & $49.4 \% *$ & $38.5 \% *$ & $46.5 \% \dagger$ & $10.9 \%$ & $13.3 \%$ & $7 \% * * \dagger$ & $0 \%$ & $2.4 \%$ & $1.3 \% \dagger$ \\
\hline Caucasian females & $36.6 \%$ & $41.5 \%$ & $39 \%$ & $39 \%$ & $36.6 \%$ & $37.8 \%$ & $12.2 \%$ & $17 \%$ & $14.7 \%$ & $12.2 \%$ & $4.9 \%$ & $8.5 \%$ \\
\hline Amerindian females & $37.8 \% *$ & $52.5 \% *$ & $45 \%$ & $31.1 \% \dagger$ & $21.3 \%$ & $26.3 \% \dagger$ & $26.2 \%$ & $19.7 \%$ & $23 \% \dagger$ & $4.9 \%$ & $6.5 \%$ & $5.7 \% \dagger$ \\
\hline
\end{tabular}

${ }^{*}$ Statistically significant difference between sides; ${ }^{*}$ Statistically significant difference between race; ${ }^{\dagger}$ Statistically significant difference between gender

Table 2. Percentage of each type of tuberculum sphenoidalis by sex and race

\begin{tabular}{|c|c|c|c|c|c|c|c|c|c|c|c|c|}
\hline & \multicolumn{3}{|c|}{ Spiniform } & \multicolumn{3}{|c|}{ Pyramidal } & \multicolumn{3}{|c|}{ Laminar } & \multicolumn{3}{|c|}{ Absent } \\
\hline & $\begin{array}{l}\text { Right } \\
\text { side }\end{array}$ & $\begin{array}{l}\text { Left } \\
\text { side }\end{array}$ & $\begin{array}{l}\text { Both } \\
\text { sides }\end{array}$ & $\begin{array}{l}\text { Right } \\
\text { side }\end{array}$ & $\begin{array}{l}\text { Left } \\
\text { side }\end{array}$ & $\begin{array}{l}\text { Both } \\
\text { sides }\end{array}$ & $\begin{array}{l}\text { Right } \\
\text { side }\end{array}$ & $\begin{array}{l}\text { Left } \\
\text { side }\end{array}$ & $\begin{array}{l}\text { Both } \\
\text { sides }\end{array}$ & $\begin{array}{l}\text { Right } \\
\text { side }\end{array}$ & $\begin{array}{l}\text { Left } \\
\text { side }\end{array}$ & $\begin{array}{l}\text { Both } \\
\text { sides }\end{array}$ \\
\hline Males & $36.2 \%$ & $42 \%$ & $39 \%$ & $44.5 \%$ & $35.1 \%$ & $40 \% *$ & $17.9 \%$ & $19.9 \%$ & $18.7 \%$ & $1.4 \%$ & $3 \%$ & $2.3 \%$ \\
\hline Females & $37.2 \%$ & $48 \%$ & $42.6 \%$ & $34.4 \%$ & $27.5 \%$ & $30.9 \% *$ & $20.6 \%$ & $18.6 \%$ & $19.6 \%$ & $7.8 \%$ & $5.9 \%$ & $6.9 \%$ \\
\hline Caucasian individuals & $34.4 \%$ & $40 \%$ & $37.2 \% * *$ & $40.6 \%$ & $33.7 \%$ & $37.2 \%$ & $20 \%$ & $22.5 \%$ & $21.2 \%$ & $5 \%$ & $3.8 \%$ & $4.4 \%$ \\
\hline Amerindian individuals & $40 \%$ & $52.2 \%$ & $43.8 \% * *$ & $42.8 \%$ & $26.1 \%$ & $36.4 \%$ & $15 \%$ & $17.2 \%$ & $16.7 \%$ & $2.2 \%$ & $4.5 \%$ & $3.1 \%$ \\
\hline
\end{tabular}

*Statistically significant difference between gender; ${ }^{*}$ Statistically significant difference between race

presented the highest and males the lowest number of TS absences in the whole sample (Table 2). The pyramidal type was more prevalent in Amerindian males than in Amerindian females $(p=0.0007)$. The laminar type and the absence of TS were more prevalent in Amerindian females than in Amerindian males ( $p=0.0001$ and $p=0.04$, respectively) (Table 1). There was a significant statistical difference between genders only in pyramidal type $(p=0.0007)$ (Table 2).

\section{Comparative analysis between left and right sides}

There was no significant difference between sides, except for the pyramidal type in Caucasian males $(p=0.006)$ and Amerindian males $(p=0.05)$, for which the right side was more prevalent and for spiniform type in Amerindian females $(p=0.05)$, for which the left side was more prevalent (Table 1).

\section{Analysis of TS symmetry}

We observed that TS type was symmetrical in $73.1 \%$ of the examined skulls. Caucasian individuals presented the highest percentage of symmetry $(73 \%)$, followed by males (71.2\%). Females and Amerindian individuals showed the lowest percentage of symmetry $(64.9 \%$ and $64.8 \%$, respectively).
In males and Caucasian individuals the spiniform and pyramidal types showed the highest percentage of symmetry. In females and Amerindian individuals the spiniform type showed the highest percentage of symmetry, followed by pyramidal type. The laminar type showed the lowest percentage of symmetry for all studied groups. The absence of TS in both sides was more frequent in females and less frequent in males; Caucasian and Amerindian individuals showed similar percentages (Table 3).

The asymmetry found more frequently was "pyramidal $\times$ spiniform" for all groups, followed by "spiniform $\times$ pyramidal" for males, Caucasian and Amerindian individuals and "laminar $\times$ pyramidal" for females. The remaining types of asymmetries were less expressive and can be observed in the Table 3 .

There was no significant difference between gender or race related to the symmetry of TS.

\section{DISCUSSION}

In our study we observed that the TS is a very frequent anatomical structure on the sphenoid bone, present in $96.3 \%$ of the skulls. Similar findings were reported by Ramalho et al. [24] who found 94.5\%, although D'Este [9] found a lower frequency of TS at $88.42 \%$. In our study we observed that the absence 
Table 3. Percentage of the types of tuberculum sphenoidalis (right and left sides) found for Caucasian males, Amerindian males, Caucasian females and Amerindian females

\begin{tabular}{lcccc}
\hline Right $\times$ left & Males & Females & Caucasian individuals & Amerindian individuals \\
\hline Spiniform $\times$ spiniform & $28 \%$ & $29 \%$ & $26.4 \%$ & $30.1 \%$ \\
Spiniform $\times$ pyramidal & $8 \%$ & $3.9 \%$ & $4.4 \%$ & $9 \%$ \\
Spiniform $\times$ laminar & $1.9 \%$ & $3.9 \%$ & $3.3 \%$ & $1.9 \%$ \\
Spiniform $\times$ absence & $0.5 \%$ & $1 \%$ & $1.3 \%$ \\
Pyramidal $\times$ spiniform & $10.9 \%$ & $13.5 \%$ & $10 \%$ & $13.5 \%$ \\
Pyramidal $\times$ pyramidal & $28.5 \%$ & $18.4 \%$ & $27.7 \%$ & $22.5 \%$ \\
Pyramidal $\times$ laminar & $2.4 \%$ & $0 \%$ & $0.6 \%$ & $2.5 \%$ \\
Pyramidal $\times$ absence & $1.4 \%$ & $1 \%$ & $2.5 \%$ & $0 \%$ \\
Laminar $\times$ spiniform & $1.4 \%$ & $1 \%$ & $1.9 \%$ & $1.3 \%$ \\
Laminar $\times$ pyramidal & $0.5 \%$ & $4.8 \%$ & $0.6 \%$ & $3.8 \%$ \\
Laminar $\times$ laminar & $14.2 \%$ & $14.5 \%$ & $17.6 \%$ & $10.9 \%$ \\
Laminar $\times$ absence & $0.5 \%$ & $1 \%$ & $0 \%$ & $1.3 \%$ \\
Absence $\times$ spiniform & $0.5 \%$ & $3 \%$ & $1.9 \%$ & $0.6 \%$ \\
Absence $\times$ pyramidal & $0 \%$ & $1 \%$ & $0.6 \%$ & $0 \%$ \\
Absence $\times$ laminar & $0.5 \%$ & $1 \%$ & $1.3 \%$ & $0 \%$ \\
Absence $\times$ absence & $0.5 \%$ & $3 \%$ & $1.3 \%$ & $1.3 \%$ \\
\hline
\end{tabular}

of TS (3.7\%) was lower than reported by D’Este [9] and Ramalho et al. [24], who found $11.58 \%$ and $5.5 \%$, respectively.

D'Este [9] reports the spiniform type as being most frequent $(53.5 \%)$, followed by pyramidal (35.5\%); in our study we found that the spiniform TS was only slightly more frequent (40.3\%) than pyramidal (37\%). Different findings were reported by Ramalho et al. [24], who found that the pyramidal type was the most frequent $(56.6 \%)$, followed by laminar (35.7\%) and finally spiniform (7.7\%). We found in our study that the laminar type was the least frequent.

In Caucasian males, Amerindian males and Caucasian females the spiniform and pyramidal types were the most frequent, followed by laminar type; in Amerindian females the spiniform type was the most frequent, followed by pyramidal and laminar types, who presented approximate percentages.

In our study we observed a higher percentage of absent TS in women compared with men. It is well known that bone responds to the direct tension, increasing its mass. This adaptation to tensile forces can lead to formation of spines, crests or tubercles. We believe that our findings are compatible with the fact that men have greater muscular potential than women.

Our results showed that in males and Caucasian individuals the spiniform and pyramidal types were the most frequent, with similar percentages and the laminar type was the less frequent; whereas in females and Amerindian individuals the spiniform type was the most frequent, followed by pyramidal and laminar types. Despite the differences observed between genders and races, only in the pyramidal type there was significant statistical difference between the sexes and only in the spiniform type there was significant statistical difference between races. No other studies were found which reported variables such as sex and race.

The type of TS shows no side preference, except for Caucasian males and Amerindian males in pyramidal type, being more prevalent on the right side in both cases; and for Amerindian females, being more prevalent on the left side.

Ramalho et al. [24] reported symmetric TS in 98.6\% of cases, higher than the percentage found in the present study (73.1\%). In females and Amerindian individuals the spiniform type showed the highest percentage of symmetry and in males and Caucasian individuals the spiniform and pyramidal types showed the highest percentage of symmetry. The asymmetry found more frequently was "pyramidal $\times$ spiniform" for all groups. Unilateral absence of TS was found more frequently than bilateral absence, except for Amerindian individuals. There was no significant difference between gender or race related to the symmetry of TS. 
Considering that the TS is a very frequent anatomical structure, and the site of origin of the deep fascicle of the temporal muscle, we firmly believe that it should be incorporated into international anatomical terminology. We agree with Ramalho et al. [24] that exact classification and proper designation are difficult due to its variable morphology. In accordance with the principles established in international anatomical terminology, the names of structures should be informative and descriptive. Considering that the most frequently found types are the spiniform and pyramidal, the terms spine and tuberculum would seem appropriate, since the former means a sharp osseous projection and the latter a small, rounded osseous relief. The term sphenoidal has a unique value in describing the topography of the TS, as this structure is located on the sphenoid bone. The term 'sphenoidal tubercle', which is the term most used in the literature, may therefore be the most appropriate.

\section{CONCLUSIONS}

In conclusion, the TS is a very frequent structure on the sphenoid bone. It presents variable forms, generally symmetrical, and there are important differences by race and gender.

The spiniform and pyramidal types are both very frequent, making it more difficult to establish the best anatomical term to designate this structure, however we believe that the term 'sphenoidal tubercle', which is the term most used in the literature, may be the most appropriate. Because of its frequent presence on the sphenoid bone, we suggest that this structure should be incorporated into international anatomical terminology.

\section{ACKNOWLEDGMENTS}

We want to thank the Department of Morphology and Genetic - UNIFESP, Brazil.

\section{REFERENCES}

1. Alves N, Cândido PL (2012) Anatomia para o curso de odontologia geral e específica. $3^{\mathrm{a}}$ Ed. Gen-Santos, São Paulo, p. 320.

2. Aprile H, Figun ME (1967) Anatomia Odontológica orocervico-facial. $4^{a}$ Ed. El Ateneo, Buenos Aires, p. 794.

3. Arnold F (1845) Handbuch der Anatomie des Menschen mit besonderer Rücksicht auf physiologie und praktische medicin. Herder'sche Verlagsbuchhandlung, Freiburg, p. 389.

4. Augier $M(1931)$ Squelette céphalique. In: Poirier $P$, Charpy $A$ eds. Traité d'anatomie humaine. Masson, Paris, p. 219.
5. Bock CE (1842) Handbuch der Anatomie des Menschen. Rengersche Buchlandl, Leipzig, p. 43.

6. Chiarugi G, Bucciante L (1975) Istituzioni di anatomia delluomo. 11 nd Ed. Società Editrice Libraria, Milano, p. 184.

7. Chipault A (1895) Instituzioni di anatomia dell 'uommo. 6nd Ed. Rueff, Paris, p. 479-482.

8. Cruveilhier J (1877) Traité d'anatomie descriptive. P Asselin, Libraire de la Faculté de Médecine, Paris, p. 852.

9. D'Este LS (1903) La ricerca e la resezione della seconda branche del trigemello nella fossa pterigopalatina, per la via retro-mascelare. Soc. Ed. Libraria Morgagni, Milano, pp. 221-372.

10. Dwight T (1907) Osteology. In: Piersol GA ed. Human anatomy. 7nd Ed. Lippincott, Philadelphia, p. 188.

11. Eisler P (1912) Die Muskeln des stammes. In: von Bardeleben $\mathrm{K}$ ed. Handbuch der anatomie des menschen. Fischer, Jena, p. 210.

12. Hartmann R (1881) Handbuch der anatomie des menschen. R Schultz Und Comp, Verlag Strassburg, p. 19.

13. Henle FGJ (1855) Handbuch der systematischen anatomie des menschen. Vieweg, Braunschweig, p. 109.

14. Hyrtl J (1882) Lehrbuch der anatomie des menschen mit rücksicht auf physiologische begründung und praktische anwendung. Wilhelm Braumüller, Wien, p. 261.

15. Lambertini G (1946) Anatomia dell' uomo. Libreria Scientifica Editrice, Napoli, p. 28.

16. Le Double AF (1903) Traité des variations des os du crane de l'homme. Et de leur signification au point de veu de I'Anthropologie zoologique. Vigot Frères Éditeurs, Paris, p. 289.

17. Mc Murrich JP (1907) Miology. In: Piersol GA ed. Human anatomy. 7nd Ed. Lippincott, Philadelphia, p. 475-476.

18. Olivier E, Dufour A (1947) Traité d'ostéologie humaine. Librairie Maloine, Paris, p. 87-140.

19. Orts Llorca F (1985) Anatomia humana. Editorial Científico-Médica, Barcelona, p. 869.

20. Paturet G (1951) Traité d'anatomie humaine. Masson, Paris, p. 88.

21. Pensa A (1933) Apparechio scheletrico. In: Pensa A, Favaro G eds. Trattato di anatomia sistematica. Unione Tipografico Editrice Torinese, Torino, p. 69.

22. Poirier $P$, Charpy A, Cunéo $B$ (1908) Abrégé $d$ 'anatomie. Masson et cie. v 1, Paris, pp. 140-471.

23. Potherat $E$ (1889) Résection du nerg maxillaire superieur. Bull Mém Soc Anat, 3: 521-522.

24. Ramalho LRT, Landucci C, Mendonça I (1988) Morfologia do tuberculum sphemoidalis do crânio humano adulto. Rev Bras Ciên Morfol, 5: 113-118.

25. Rauber A (1892) Lehrbuch der anatomie des menschen. E Besold, Leipzig, p. 205-424.

26. Rouvière $H$ (1948) Anatomie Humaine descriptive et topographique. Masson, Paris.

27. Sappey PH C (1876) Traité d'anatomie descriptive. V. Adrien Delahaye et Cie, Paris.

28. Spee FG von (1896) Skelettlehre. In: Bardeleben K von. Handbuch der anatomies des menschen. Fischer, Jena.

29. Testut L, Jacob O (1956) Tratado de anatomía topográfica con aplicaciones médico quirúrgicas. $8^{\mathrm{a}}$ Ed. Salvat Editores, Barcelona:

30. Testut L, Latarjet A (1959) Tratado de anatomía humana. Salvat Editores, Barcelona. 